University of New Haven

University of

New Haven

Digital Commons@ New Haven

Civil Engineering Faculty Publications

Civil Engineering

$12-2016$

\title{
Economic Feasibility of Campus-Wide Photovoltaic Systems in New England
}

Jongsung Lee

University of New Haven

Byungik Chang

University of New Haven, BChang@newhaven.edu

Can B. Aktas

University of New Haven, caktas@newhaven.edu

Ravi Gorthala

University of New Haven, rgorthala@newhaven.edu

Follow this and additional works at: http://digitalcommons.newhaven.edu/civilengineering-facpubs Part of the Civil Engineering Commons

\section{Publisher Citation}

Lee, J., Chang, B., Aktas, C., \& Gorthala, R. (2016). Economic feasibility of campus-wide photovoltaic systems in New England. Renewable Energy, 99, 452-464.

\section{Comments}

This is the authors' accepted version of the article published in Renewable Energy. The version of record is available at http://dx.doi.org/10.1016/ j.renene.2016.07.009 


\title{
Economic Feasibility of Campus-Wide Photovoltaic Systems in New England
}

\author{
Jongsung Lee ${ }^{a}$, Byungik Chang ${ }^{\mathrm{b} *}$, Can Aktas ${ }^{\mathrm{c}}$, Ravi Gorthala ${ }^{\mathrm{d}}$ \\ ${ }^{a}$ Research Assistant, Department of Civil and Environmental Engineering, University of New \\ Haven, West Haven, Connecticut 065616, USA \\ ${ }^{\mathrm{b}}$ Associate Professor, Department of Civil and Environmental Engineering, University of New \\ Haven, West Haven, Connecticut 065616, USA \\ ${ }^{\mathrm{c}}$ Assistant Professor, Department of Civil and Environmental Engineering, University of New \\ Haven, West Haven, Connecticut 065616, USA \\ ${ }^{\mathrm{d}}$ Associate Professor, Department of Mechanical and Industrial Engineering, University of New \\ Haven, West Haven, Connecticut 065616, USA \\ * Corresponding author

\section{Byungik Chang, PhD, PE, MBA} \\ Associate Professor of Civil Engineering \\ Department of Civil and Environmental Engineering \\ University of New Haven \\ 300 Boston Post Road \\ West Haven, CT 06516 \\ Tel: 203-479-4234 \\ Fax: 203-931-6087 \\ Email: bchang@newhaven.edu
}

\begin{abstract}
Compared to the national average residential retail electricity price, Connecticut $(\mathrm{CT})$ had the $4^{\text {th }}$ highest electricity price in the country with 19.23 cents/kWh in September 2015, nearly 50\% higher than the national average for price of electricity. This study aims to assess the economic feasibility of the solar PV systems at the campus under realistic constraints, by analyzing actual data from the solar array on campus. The project focused on the economic feasibility of solar PV systems on campus with physical, spatial, and practical constraints that result in a project to deviate from theoretical (estimated) values. To achieve that, the prediction of the PV power generation from the building was developed and compared with the actual (measured) data.

The average payback period of a campus-wide PV system was calculated as primarily 11 years, within a range of 8-12 years, and was estimated to reduce overall building operating expenses by $\$ 250,000$, or $8 \%$. The economic parameters such as NPV and IRR also validated the investment worthiness. The results of the study could be used to analyze or further develop feasibility studies of PV systems at other universities in Connecticut and neighboring states that share similar climatic characteristics and economic factors.
\end{abstract}


Keywords

2 Renewable energy; Solar photovoltaic; Economic feasibility study; Environmental

3 impact; Campus-wide PV; New England

4

Original Submission Date: December 29, 2015

22 Revision Submission Date: April 30, 2016

23 Word Count: Abstract - 199, Text - 7,959, 9 Figures, and 10 Tables

24 No. of Page: 26 


\section{Introduction}

In 2014, the U.S. generated about 4,093 billion kWh of electricity, of which approximately $67 \%$ were derived from fossil fuels, namely coal, natural gas, and petroleum. The share of renewable energy sources in the electricity grid were minimal, with electricity from wind contributing $4.4 \%$, and solar $0.4 \%$ [1]. The problems are exacerbated not only due to consumption of non-renewable fuel sources for electricity generation, but when these facts are evaluated in light of the 2015 United Nations Climate Change Conference, also known as the 2015 Paris Agreement to Combat Climate Change, in which participating countries have agreed to work towards keeping global temperature rise below $2{ }^{\circ} \mathrm{C}$ compared to pre-industrial levels [2].

The Paris Agreement acknowledges that meeting this goal will require all countries to take steps to curb their greenhouse gas emissions as soon as possible. Even before signing of the international Agreement, the U.S. had committed to reduce its greenhouse gas emissions by 26$28 \%$ from the 2005 levels by the year 2025 [3-4]. Considering that the electricity sector was the largest source of U.S. greenhouse gas emissions in 2013 and was responsible for $31 \%$ of the total amount of 6,673 million metric tons of $\mathrm{CO}_{2}$, it is evident that policies and agreements that aim to curb greenhouse gas emissions would not succeed by disregarding the electricity sector [5].

Switching to renewable forms of energy has important economic and social benefits in addition to direct environmental benefits in the form of less pollution derived from energy generation. Creation of new green jobs, developing a more resilient energy infrastructure, and enabling a more competitive energy market would benefit the society overall while opening new markets and sectors for growth [6].

A necessity for solar PV technology to gain a foothold and provide a noticeable portion of grid electricity in the U.S. is that cost of electricity from solar PV must be economically competitive with other, more conventional forms of electricity generation [7]. This requirement by itself may not be too difficult as historical trends indicate a rapidly declining cost for solar PV technologies and an exponentially increasing installed capacity, as presented in Figure 1.

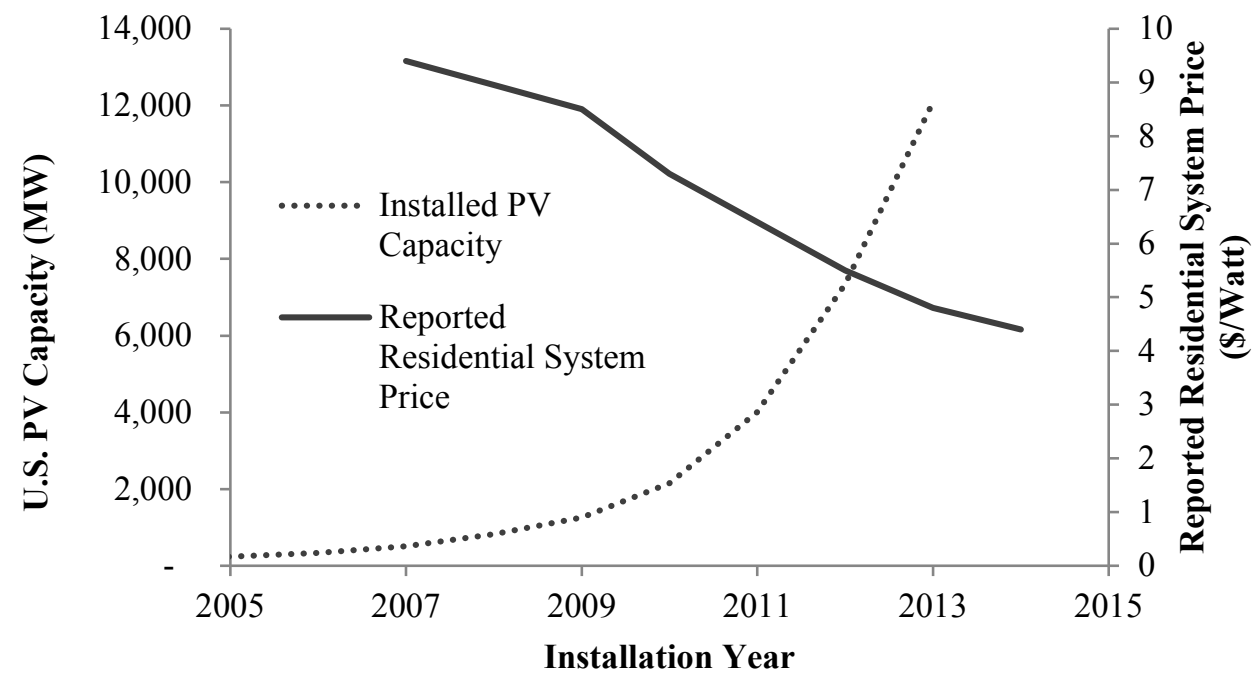

28

29

30

31

Figure 1. U.S. Solar PV installed capacity and reported residential system price [8-10]. 
Solar PV applications in the U.S. were not distributed uniformly. In 2015 , almost $40 \%$ of distributed PV capacity was located in California, and the next 9 top states had a share of 44\%. The remaining 40 states and the District of Columbia shared the remaining 16\% installed capacity. As of September 2015, Connecticut was the $10^{\text {th }}$ state with the largest installed solar PV capacity with $129 \mathrm{MW}$ [11].

Through research efforts via the Sunshot Initiative under the U.S. Department of Energy's Office of Energy Efficiency and Renewable Energy, the cost of solar PV has been reduced drastically in recent years. A significant drop in utility-scale cost of electricity from PV projects has been reported in a few years since program initiation, with installed costs dropping from 21.4 cents $/ \mathrm{kWh}$ in 2010 to 11.2 cents/ $\mathrm{kWh}$ in 2013 , with a further goal to reduce costs to 6 cents/kWh by 2020 [12]. Even with the 2013 unit price, solar PV is already cost-competitive with traditional energy sources for electricity generation in certain states and regions. The electricity price in Connecticut is one of the highest in the nation. Compared to the national average residential retail electricity price of 13.06 cents $/ \mathrm{kWh}$, Connecticut had the $4^{\text {th }}$ highest electricity price with 19.23 cents/kWh in September 2015, nearly 50\% higher than the national average for price of electricity [13].

Ma, et.al. [14] investigated the quantified impacts of climate change on the future performance of PV roof system with a general electricity load and legal maximum size of solar array. The morphing method in the study was employed and simulated the long-term implementation of the systems in Australian states. Results show that for the PV system in the majority of cities, a 10-20\% increase of economic costs between the 2030 and 2050 climate scenario would be required.

A study conducted by Baurzhan, et.al. [15] shows that with an estimated annual rate of decrease in PV system costs of 4\% and $7.67 \%$ in Sub-Saharan Africa, solar home systems are expected to become very competitive with conventional diesel electricity generators within 9 to 17 years. This study also insists of necessity of government incentives for the initial development in PV market. A similar cost-effective policy study [16] was conducted in India.

The Desert Research Institute [17] installed eight solar PV systems in Nevada with total nameplate capacity of $2.4 \mathrm{MW}$. The PV systems supply approximately $40 \%$ of total electricity used at DRI's two campuses. For the six systems larger than $50 \mathrm{~kW}$, the simple payback period of 14.4 to 26.7 years were estimated, and 25 year return on investment showed double for some systems. Another solar PV feasibility study [18] details the multi-level estimation methodology used to estimate rooftop PV potential in the commercial and residential sectors in three states including California, Arizona, and New Jersey. Those three states account for two-thirds of the cumulative installed PV capacity in the U.S. The estimation methodology in the study shows that rooftop PV could provide $35 \%, 43 \%$, and $61 \%$ of state electricity demand in New Jersey, Arizona, and California, respectively. The paper concluded that these states could increase current installed distributed PV capacity by 20,30, and 40 times, respectively.

Perhaps an equally significant barrier to further advancing the system-wide integration of solar PV would be the lack of public awareness of the potential benefits of the technology. The social and economic barriers of actual and perceived cost differential between electricity price of solar and conventional sources of energy, together with a lack of awareness of the potential applications of PV technology into the built environment remains to be solved for solar PV to achieve desired market penetration.

University campuses are prime targets to implement solar PV technology for multiple reasons. They act as incubators for new ideas and places where research takes place. They also 
educate future generations not solely in their respective discipline, but also by the physical environment that they are exposed to. Hence, exposure to solar PV through campuses combined with effective communication on generation rates and the feasibility of the system would contribute towards overcoming the social and economic barriers related to solar PV technologies. A more pragmatic reason for campuses to implement solar PV would be the American College and University Presidents' Climate Commitment (ACUPCC) agreement, where commitments are made to reduce campus-wide greenhouse gas emissions and environmental impacts. There were 679 signatory institutions as of 2014 , which cumulatively represent $41.6 \%$ of U.S. students in higher education [19-20]. As was discussed previously, an effective policy aiming to curb greenhouse gas emissions must take energy generation into account.

A $42 \mathrm{~kW}$ PV system and a $50 \mathrm{~kW}$ wind turbine system were installed to reduce energy use from the electrical grid consumption at West Texas A\&M University (WTAMU). Alternative Energy Institute (AEI) [21] at WTAMU performed the installation of the PV and wind turbine systems and conducted feasibility study. The AEI also developed the solar and wind maps that show potential renewable energy places in Texas.

The goal of the study was to assess the economic feasibility of expanding solar PV systems at the University of New Haven (UNH) campus under realistic constraints, by analyzing data from a recently implemented solar array on campus. To achieve that, the prediction of the PV power generation from the building was developed and compared with the actual (measured) data. The results of the study could be used to assess the feasibility of PV systems at other universities in the state of Connecticut (CT) that share similar climatic characteristics and economic factors. Solar energy generation was estimated by using actual weather data and by determining favorable roof pitches and cardinal directions of UNH buildings. The payback periods were estimated individually for each building and optimal buildings have been identified. Other universities especially in CT and the New England region could directly benefit from the economic analysis presented here as they would have similar, if not exactly the same, electricity costs as well as offered incentives.

\section{Background}

\subsection{University of New Haven (UNH) Campus}

UNH is located in West Haven, Connecticut, and thereby lies in the Northeast region of the U.S. A solar insolation map (see Figure 2) developed by NREL in 2012 indicates that the state of CT overall has $4.5-5.0 \mathrm{kWh} / \mathrm{m}^{2} /$ day of PV solar resource [22], which places the region in an average rating for solar resource. As for other climatic characteristics, the region has a humid continental climate with hot summer days. The daily temperature typically varies between $-4^{\circ} \mathrm{C}$ and $29^{\circ} \mathrm{C}$ over the course of a year and seldom drops below $-12^{\circ} \mathrm{C}$ or goes above $31^{\circ} \mathrm{C}$. Annually, 206 days equivalent to about 2,600 hours of sunshine are present, with a distribution as shown in Figure 3. Geographically, the campus is located in the northern hemisphere with a latitude of $41.29^{\circ}$ and a longitude of $-72.96^{\circ}$. 


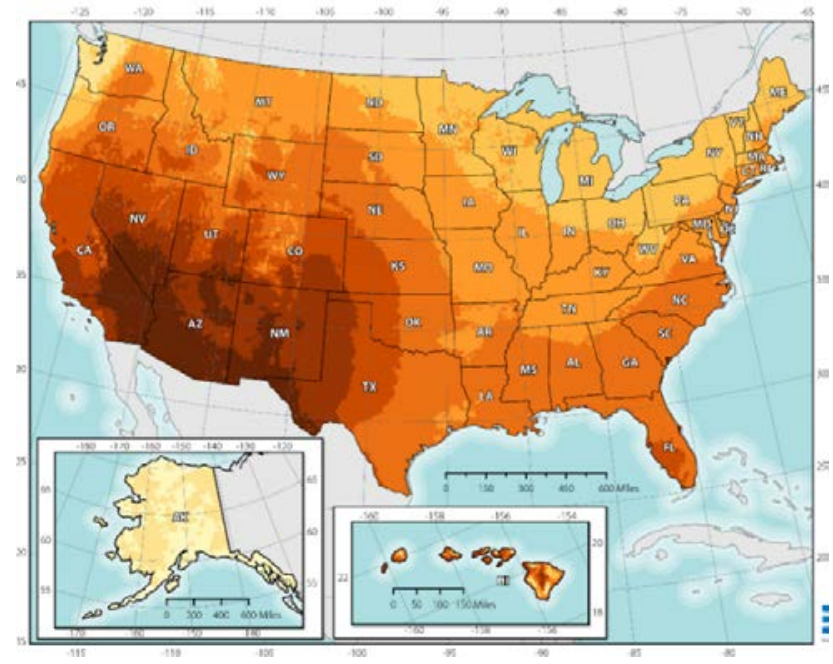

(a) The U.S.

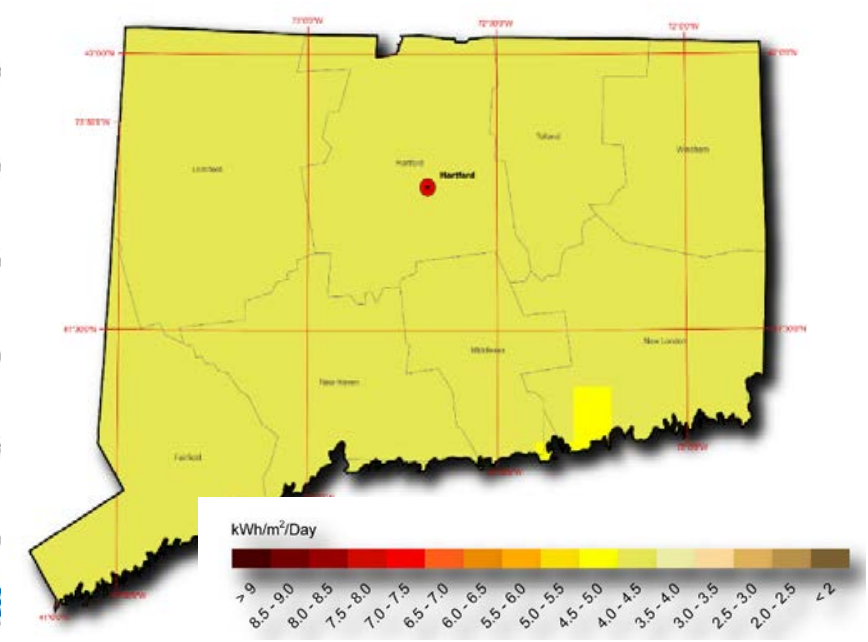

(b) Connecticut

3 Figure 2. Solar resource map of the U.S. and Connecticut

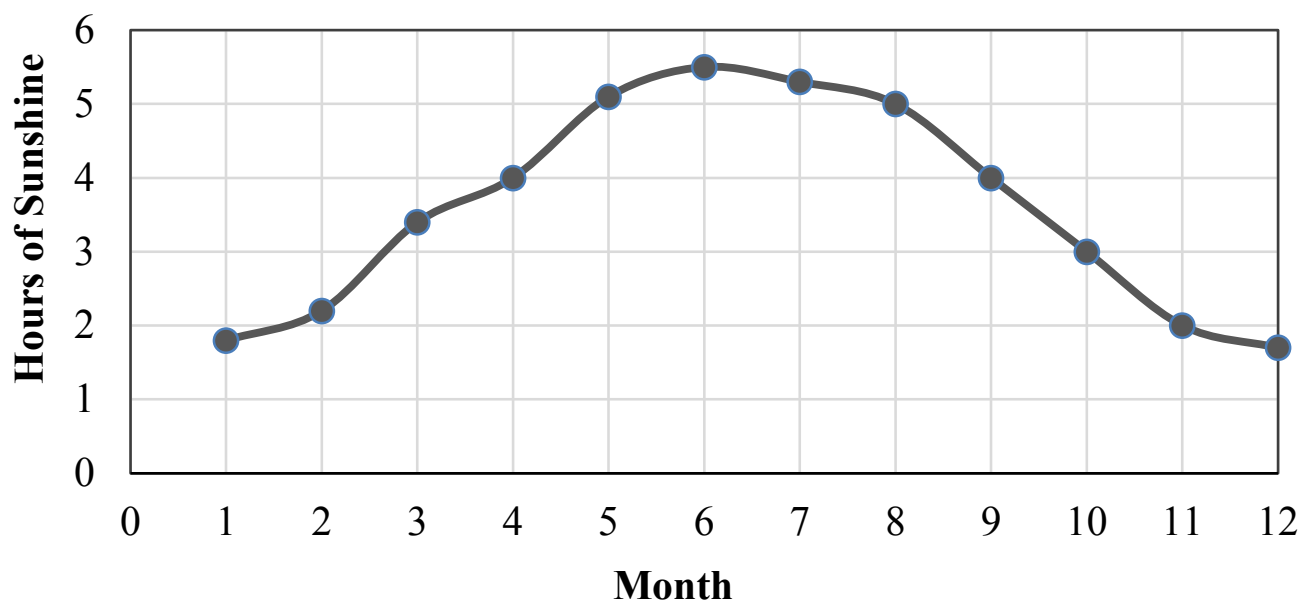

Figure 3. Average monthly solar insolation in Connecticut

UNH is a medium-sized Master's level institution of higher education with over 6,000 undergraduate and graduate students. The main campus is located in a suburban setting, and is surrounded by residential zones. As land on campus is scarce, and opportunities for expansion are hampered by surrounding existing development, the optimal location for a solar PV system would be the roofs of buildings on campus. There are 26 buildings on the UNH campus with a total of $30,000 \mathrm{~m}^{2}$ of roof area that was found to be structurally suitable for solar PV implementation.

\subsection{Celentano Hall PV System}

Celentano Hall was the first green building certified by the U.S. Green Building Council at the University of New Haven campus. The building has received LEED gold certification 
status. Celentano Hall is an upper classman residence hall for undergraduate students living on campus. The building has 402 beds and is occupied primarily by juniors and seniors.

A solar PV array was implemented on the roof of the building recently, which provided actual data analyzed in this study. The system consisted of 228 modules of Hanwha HSL 72 model on Panelclaw Polar Bear racking and three Solectria inverters [23]. Based on an active islanding detection technique [24], three inverters were used in the system to improve efficiency. The fixed panel array system of 228 PV modules were south facing with an inclination of 12 degrees. Considering $5 \%$ to $10 \%$ of the total energy generated is needed to operate the tracking system, fixed panels were determined to be more economically feasible for the Celentano Hall PV system [25]. Figure 4 was taken during system installation, where the inclination can be observed. The installation of the fixed mount array with a system size of $67.27 \mathrm{~kW}$ was finished in December 2014, and the PV system has started generating electricity in January 2015. Table 1 further presents the specifications of the installed PV system on Celentano Hall. While PV module design lifetime was taken as 25 years based on the manufacturer's guarantee period, research has shown that lifetime of PV modules may extend well beyond 25 years [26].

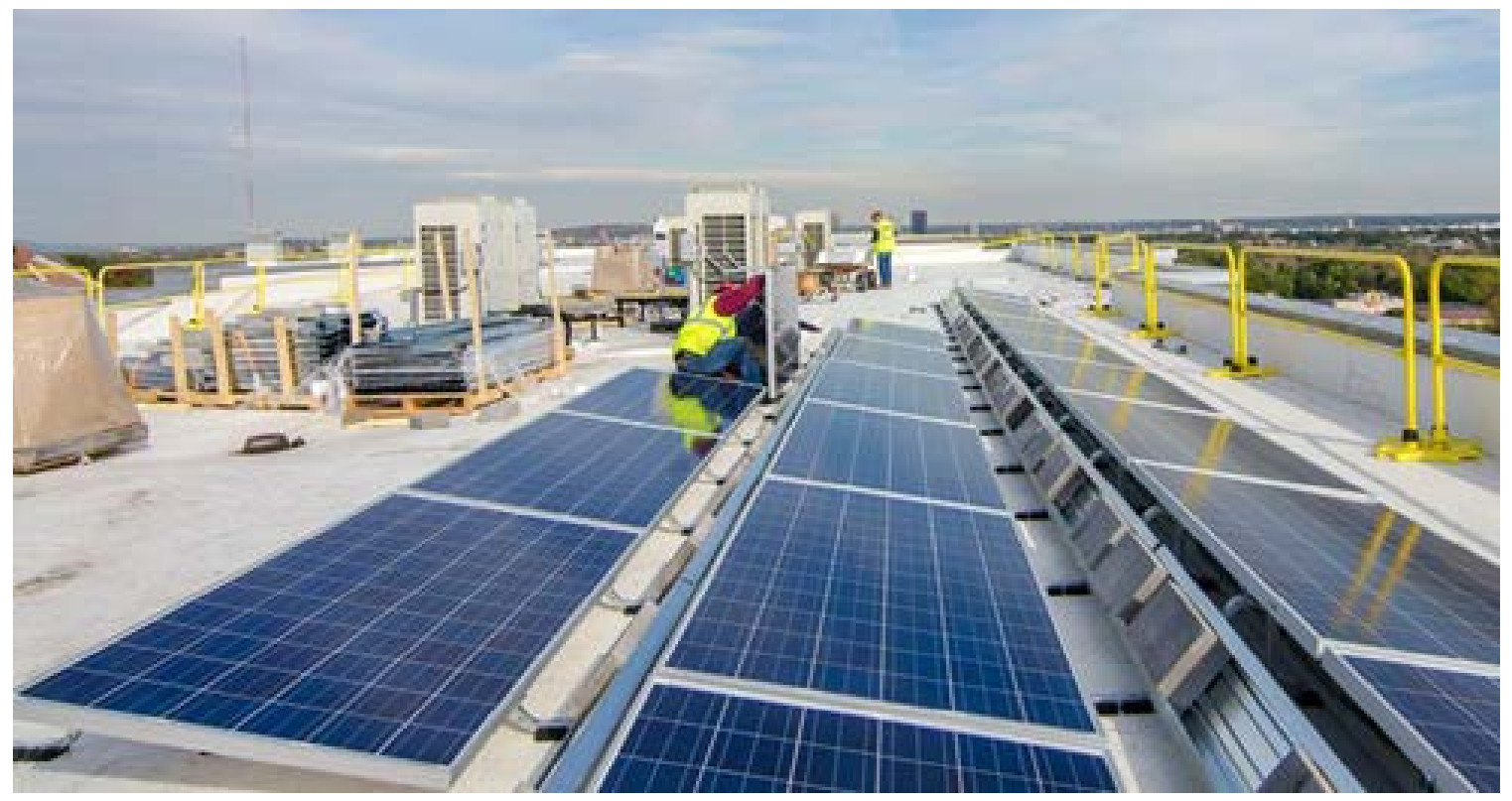

Figure 4. PV module on the rooftop of Celentano Hall

While the total roof area of Celentano Hall is $2,186 \mathrm{~m}^{2}$, a measurement for the entire roof area cannot be used in array size calculations due to several technical factors. The array size needs to be designed to avoid shading caused by parapets on the sides of the roof in order to maximize unit efficiency, and also to leave gaps between front row modules and those behind it, as the modules are at an incline rather than lie flat on the surface, and thus create the potential to shade modules placed behind them. Furthermore, PV modules are typically set 4-6 feet from the edges of a roof for safety reasons, as well as to provide accessibility during maintenance visits. Also, the roof of an existing building, as was the case with Celentano Hall, already contained obstacles such as AC units and water tanks that required the PV design to conform around those objects. Existing objects on the roof of Celentano Hall together with the final layout of the PV array system fitted based on project constraints is presented in Figure 5. 
Table 1. Celentano Hall PV system specifications and design criteria used in the analysis [23-27]

\begin{tabular}{|c|c|c|c|}
\hline Roof Height & 55 feet & $\begin{array}{l}\text { Module Brand and } \\
\text { Model }\end{array}$ & $\begin{array}{l}\text { Hanwha HSL 72P6-PB- } \\
\text { 4-300Q }\end{array}$ \\
\hline Module Inclination & 12 degrees & Module Surface Area & $1.93 \mathrm{~m}^{2}$ \\
\hline $\begin{array}{l}\text { Azimuth (West/East } \\
\text { Building) }\end{array}$ & $\begin{array}{l}152 / 134 \\
\text { degrees }\end{array}$ & Module Efficiency & $15.50 \%$ \\
\hline Setback from Roof Edge & 4 feet & Racking & Panelclaw Polar Bear III \\
\hline Roof Parapets & 2 feet & Inverter & Solectria PVI20TL \\
\hline Temperature Range & $6-91^{\circ} \mathrm{F}$ & Connection & Grid Inter-Tie \\
\hline Design Wind Speed & $110 \mathrm{MPH}$ & System Capacity & $67.26 \mathrm{~kW}$ \\
\hline $\begin{array}{l}\text { Estimated Annual Module } \\
\text { Degradation }\end{array}$ & $0.5 \%$ & $\begin{array}{l}\text { Module Design } \\
\text { Lifetime }\end{array}$ & 25 Years \\
\hline
\end{tabular}

2

The total panel area can be calculated by multiplying the number of modules installed and the surface area of each module, thereby yielding $440 \mathrm{~m}^{2}$. By comparing the resulting number with the total roof area of $2,186 \mathrm{~m}^{2}$, it is clear that the system size implemented may be significantly smaller than the roof area of a building.

\subsection{Solar PV Installations in Other Institutions of Higher Education in Connecticut}

Through the National Center for Education Statistics, the Department of Education lists 28 universities and colleges in the state of Connecticut that offer a Bachelor's or higher degree. However, the Association for Advancement of Sustainability in Higher Education (AASHE) list only 7 higher education institutions that have an installed PV system. Reviewing publicly available information of the remaining 21 institutions did not yield further information. The PV system installed by UNH and analyzed in this study was not yet reported by AASHE but has been added to Table 2, which presents the 8 higher education institutions in CT that have an installed PV system on campus together with their installed capacity.
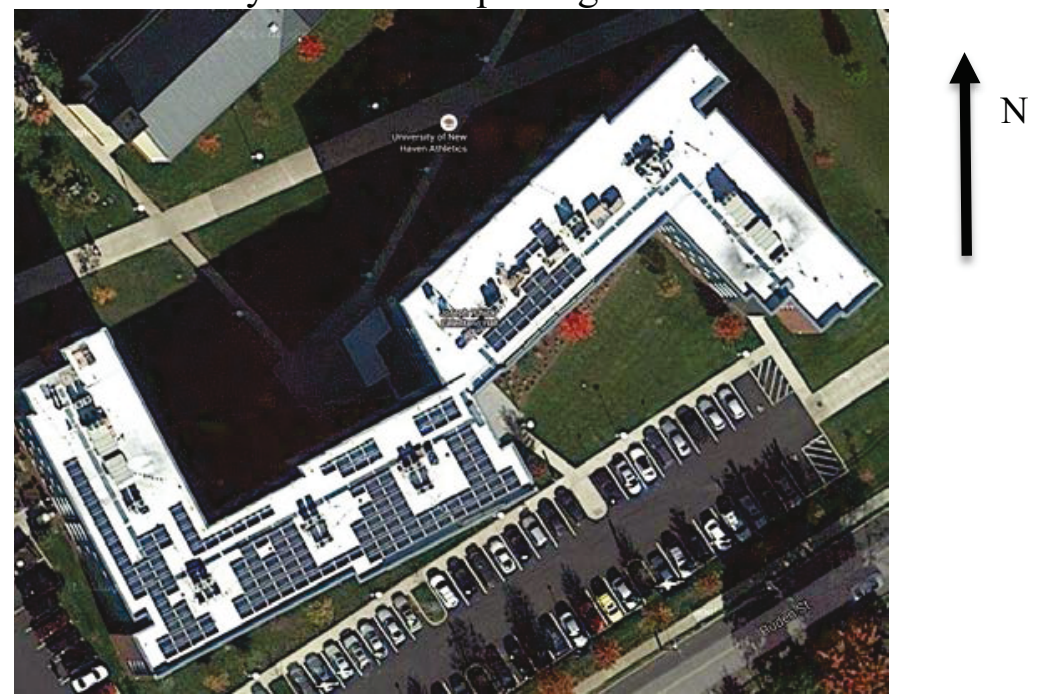

Figure 5. Aerial view of Celentano Hall PV array 
Table 2. List of higher education institutions in Connecticut with PV systems [28-32]

\begin{tabular}{lcc}
\hline Institution Name & Year Completed & Capacity (kW) \\
\hline Connecticut College & 1998 & 43 \\
& 1999 & 10 \\
Fairfield University & 2001 & 15 \\
Quinnipiac University & 2010 & 224 \\
Southern Connecticut State University & 2011 & 50 \\
University of Hartford & 2006 & 17 \\
University of New Haven & 2014 & 67 \\
Wesleyan University & 2008 & 7 \\
& 2012 & 200 \\
Yale University & 2007 & 40 \\
& 2009 & 25 \\
& 2010 & 100 \\
& 2015 & 1,250 \\
\hline
\end{tabular}

It is also important to keep the environmental benefits of such PV installations in perspective. As an alternative to traditional fuel sources, electricity generation from PV systems avoids $\mathrm{CO}_{2}$ emissions associated with electricity generation. While there have been different attempts to account for avoided $\mathrm{CO}_{2}$, a recent prominent method that was developed by EPA is the Avoided Emissions and Generation Tool (AVERT). The primary intent of the tool was to enable states and other interested stakeholders to assess air pollution reduction measures [33]. Accordingly, utility scale PV systems in the Northeast region of the U.S. would avoid 0.53 tons of $\mathrm{CO}_{2}$ per MWh [34]. The value was verified by comparing to results of recent studies. A news article regarding Yale University's most recent plans to install a 1,250 kW PV array reports estimated electricity generation of 1.6 million $\mathrm{kWh}$ annually, where the system would reduce 16,000 metric tons of $\mathrm{CO}_{2}$ emissions over its life time [35]. Assuming a 20 year design lifetime, the coefficient for avoided tons of $\mathrm{CO}_{2}$ per MWh can be calculated to be in accordance with the results from the AVERT tool.

Another study conducted by University of Connecticut for their main campus in Storrs, estimated similar results for avoided $\mathrm{CO}_{2}$ emissions. It was reported that a PV system with a 10 $\mathrm{kW}$ size would be expected to generate $11,520 \mathrm{kWh}$ per year, and reduce $10,575 \mathrm{lbs}$. of $\mathrm{CO}_{2}$ emission annually [36]. However, this study was also important as their research aimed to calculate economic viability of renewable energy technologies by including initial cost and total cash flow, but also addressed other benefits such as avoided greenhouse gas emissions, and enhanced education and research opportunities. Nevertheless, the report concludes that for PV systems to be a viable alternative, there needs to be strong government support in the form of grants, tax credits, or accelerated depreciation benefits [36]. A major shortcoming of the report is its lack of a transparent economic model that other universities in the region could benefit from. It is intended that the current study would fill an information gap in this field and aid other universities interested in installing PV systems on campus. 


\subsection{Regional Economic Impacts of PV Systems}

The Jobs and Economic Development Impact (JEDI) Model developed by NREL can be used to estimate the economic impact of renewable energy installations for a specific region. Economic impacts related to on-site labor impacts, local revenue and supply chain impacts, as well as induced impacts are captured within the tool [37]. There have been studies that assessed the jobs impact of solar PV applied at the state level in the U.S., or in other countries [38-43]. Rather than apply the tool at the state level however, an analysis was conducted as part of the study for the PV system installed at Celentano Hall, as well as an additional analysis to assess the economic impacts of expanding solar PV installations to the entire campus.

\subsection{Procurement Strategies}

There are two different procurement strategies for installing PV systems on university campuses. Each strategy can benefit from different types of financial incentives. The first strategy is to have a third-party private company own the solar array and lease them to the university. In this case, the university would need to make a power purchase agreement (PPA) with the company, usually at a higher electricity rate than what would have been paid to the supplier utility. The third-party company takes advantage of tax credits and deductions offered at the federal and state levels. The university would be relieved of high initial installation costs associated with PV array systems.

The second strategy would be for the university to be the sole owner of the PV system. While this strategy prevents campuses from paying higher electricity rates to a third-party company through a power purchase agreement, as most colleges and universities in the U.S. are non-profit institutions, they cannot take advantage of the $30 \%$ tax credit on installation costs, hence affecting the feasibility of the system and reflecting on electricity rates generated throughout the life of the system.

Regardless, UNH opted for the second option of owning the PV system as it was deemed a better alternative as a long-term investment compared to buying back electricity at a higher rate through a PPA. However, UNH was able to benefit from the Zero Emission Renewable Energy Credits (ZRECs) incentive offered by the state.

\subsubsection{Zero Emission Renewable Energy Credits (ZRECs)}

In July 2011, the state of Connecticut enacted legislation amending the state's renewable portfolio standards and created new classes of renewable energy credits for PV systems with a project size larger than $100 \mathrm{~kW}$ and up to $1 \mathrm{MW}$ in nameplate capacity [44]. The amount of ZRECs award depends on the amount of electricity generated; therefore, the amount decreases every year because of the degradation factor $(0.50 \%)$ of PV modules. ZRECs were awarded to the installed Celentano Hall PV system. A PV system with capacity greater than $100 \mathrm{~kW}$ qualify for reverse auctions, and systems with capacity less than $100 \mathrm{~kW}$ would earn benefits through a lottery system. Being below the $100 \mathrm{~kW}$ cutoff level, UNH could still receive substantial financial support for 15 years as long as the system continues to operate as designed. Celentano Hall was awarded $\$ 0.148 / \mathrm{kWh}$ electricity generation by the PV system.

\section{Methods}

The goal of the study was to assess the economic feasibility of expanding solar PV systems on the UNH campus by analyzing data from a recently implemented array on campus, and to develop an economic model for use by other universities in Connecticut (CT) which share 
similar climate characteristics and economic factors. Even though actual data were collected during the study, estimation of electricity generation was deemed necessary to forecast future performance of the array, which would then be used in the economic model. The annual energy production was estimated by using the PVWATTS Calculator together with local and system variables that were input into the calculator. The payback periods were estimated individually for each building and optimal buildings have been identified.

\subsection{Estimated Electricity Generation}

In order to conduct an economic analysis, an estimated energy production of the PV system was deemed necessary. Quantitative equations were used to calculate estimated power produced by the PV array. Eq. (1) was used to estimate solar energy generation for a flat-plate collector, facing south at a fixed tilt.

$$
\mathrm{E}=\mathrm{A} \cdot \mathrm{r} \cdot \mathrm{h} \cdot \mathrm{pr}
$$

Where; $\mathrm{E}$ is the annual estimated electricity production in $\mathrm{kWh}, \mathrm{A}$ is the total solar panel area in $\mathrm{m}^{2}, \mathrm{r}$ is solar panel efficiency, $\mathrm{h}$ is annual average solar radiation in $\mathrm{kWh} / \mathrm{m}^{2}$, and $\mathrm{pr}$ is the system performance ratio.

The power incident on a solar panel depends on the solar radiation and the angle between the module and the sun as shown in Figure 6 . The power density on the module surface is at maximum when the tilt angle makes the module perpendicular to sunlight. However, the declination angle, $\alpha$, is changing during the day and therefore, the power density of a fixed PV module is less than solar insolation.

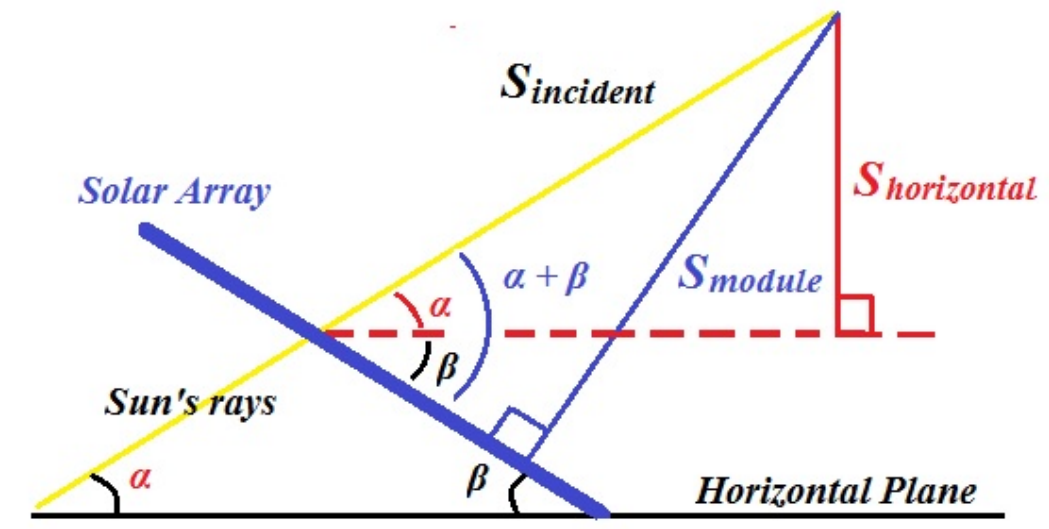

Figure 6. Solar radiation on a tilted surface

Average solar radiation data from two different data collecting centers was used in the calculation for more accurate estimation. UNH campus is located at $41.29^{\circ}$ latitude between Bridgeport and Hartford, where weather data collection centers exist. Accordingly, average horizontal solar radiation at these two sites was both equal to $3.8 \mathrm{kWh} / \mathrm{m}^{2} /$ day, and hence the same value was used to estimate electricity generation at the UNH campus [45].

Trigonometric analysis was performed to estimate annual average solar radiation. In order to calculate the $\mathrm{S}_{\text {module }}$ shown in Figure $6, \alpha$, which is the angle between sunlight and the horizontal plane can be calculated using equations (2) and (3).

$$
\begin{aligned}
& \alpha=90-\varphi+\delta \\
& \delta=23.45 \cdot \sin ((360 / 365) \cdot(284+d))
\end{aligned}
$$


where; $\alpha$ is the elevation angle, $\varphi$ is the latitude, and $\delta$ is the declination angle. Equation (3) calculates declination angle of a specific day of a year, and the value ranges in between -23.45 on the first day of the year to +23.45 on the last day of the year. The elevation angle for the Celentano hall PV system is calculated to be 48.71 degree. The total annual average solar radiation can be calculated using Equation (4),

$$
\mathrm{S}_{\text {module }}=\mathrm{S}_{\text {horizontal }} \cdot \sin (\alpha+\beta) / \sin \alpha
$$

where; $\beta$ is the tilt angle of the module measured from the horizontal.

Performance ratio is a measure of the overall efficiency of a PV system, and covers efficiency losses related to interconnected parts and conversion inefficiencies, and is independent of location, or the amount of sunlight received. It represents a ratio of actual energy generation to energy that can theoretically be generated. Values input into the PVWATTS calculator were presented in Table 3. An overall derate factor of 0.75 was found for the Celentano PV system, and was used in the study for estimating electricity generation by the installed system.

Table 3. Derate factors for AC power rating at STC

\begin{tabular}{lcc}
\hline Component Performance Ratio & PVWATTS Default & Range \\
\hline Module Nameplate DC Rating & 0.95 & $0.80-1.05$ \\
Inverter and Transformer & 0.92 & $0.88-0.98$ \\
Mismatch & 0.98 & $0.97-0.995$ \\
Diodes and Connections & 0.98 & $0.99-0.997$ \\
DC Wiring & 0.98 & $0.97-0.99$ \\
AC Wiring & 0.98 & $0.98-0.993$ \\
Soiling & 0.95 & $0.30-0.995$ \\
System Availability & 0.98 & $0.00-0.995$ \\
Shading & 1 & $0.00-1.00$ \\
Age & 1 & $0.70-1.00$ \\
Overall DC-to-AC Derate Factor & $\mathbf{0 . 7 5}$ & \\
\hline
\end{tabular}

The solar radiation incident is relatively constant above the atmosphere, while the radiation at the Earth's surface varies by atmospheric effects, latitude of the location, and the time of day relative to year. In addition, to enhance the accuracy of solar irradiation forecasting, the clearness index was also considered. Clearness index $\left(\mathrm{K}_{\mathrm{T}}\right)$ is the fraction of the solar radiation transmitted through the atmosphere to reach a horizontal plane at a particular location of the Earth as shown in Equation (5). $\mathrm{K}_{\mathrm{T}}$ indicates how much of the Sun's radiation is attenuated due to scattering and absorption in the atmosphere, and thus is important measure for the PV analysis. Table 4 shows the monthly and annual clearness index in two locations

25 (Bridgeport and Harford) near the project location.

$$
\overline{K_{T}}=\frac{\bar{H}}{\bar{H} o h}
$$
where; $\bar{H}$ is the monthly average daily irradiation on a horizontal plane at the Earth's surface and $\bar{H} o h$ is the monthly average daily value of extraterrestrial radiation energy falling on a horizontal 29 plane. 
Table 4. Monthly and Annual Clearness Index $\left(\mathrm{K}_{\mathrm{T}}\right)$ in Connecticut

\begin{tabular}{lccccccccccccc}
\hline \multicolumn{1}{c}{ CITY } & JAN & FEB & MAR & APR & MAY & JUN & JUL & AUG & SEP & OCT & NOV & DEC & YR \\
\hline \hline BRIDGEPORT & 0.45 & 0.48 & 0.48 & 0.48 & 0.49 & 0.5 & 0.51 & 0.51 & 0.5 & 0.48 & 0.43 & 0.42 & 0.49 \\
HARTFORD & 0.47 & 0.49 & 0.48 & 0.48 & 0.49 & 0.51 & 0.52 & 0.51 & 0.49 & 0.47 & 0.42 & 0.42 & 0.49 \\
\hline
\end{tabular}

\subsection{Economic Analysis}

Table 5 shows the financial factors used for the economic analysis calculation. Factors discussed in academic literature [20], as well as other deemed necessary were included in the analysis. The annual electricity usage by Celentano Hall was 1,425,900 kWh, and the current electricity rate for the building was $\$ 0.17 / \mathrm{kWh}$. An annual electric cost increase of $3.5 \%$ was calculated from the average of residential electricity price increases in the U.S. between 2004 and 2014, and was factored into the calculations during the study [40]. The estimated insurance on the PV system was $0.17 \%$ of the total installation cost, which is expected to increase by the annual inflation rate of 3.0\% [47]. The annual operation and maintenance costs were estimated to be $\$ 10 / \mathrm{kW}$-year [48].

Table 5. Financial factors for the Celentano Hall PV system

\begin{tabular}{lrllrl}
\hline No. of Solar Panels & 228 & Panels & Installation Costs & $\$ 288,500$ & Turn Key \\
PV Array Size & 67.27 & $\mathrm{DC} \mathrm{kW}$ & Maintenance & $\$ 10.00 / \mathrm{kW} / \mathrm{yr}$ \\
Annual Solar Production & 82,800 & $\mathrm{kWh} / \mathrm{yr}$ & ZREC Reward & $\$ 0.15 / \mathrm{kWh}$ \\
Electricity Usage & $1,425,900$ & $\mathrm{kWh} / \mathrm{yr}$ & ZREC Escalator & $0.50 \% / \mathrm{yr}$ \\
Module Efficiency & 15.5 & $\%$ & ZREC Term & $15 \mathrm{yrs}$ \\
Module Degradation & -0.5 & $\% / \mathrm{yr}$ & Interest Rate & $5 \%$ & $3 \% / \mathrm{yr}$ \\
Electric Cost Escalation & 3.5 & $\% / \mathrm{yr}$ & Inflation Rate & $3 \% \%$ \\
Current Electricity Rate & 0.17 & $\$ / \mathrm{kWh}$ & Insurance & $0.17 \%$ & \\
& & & Marginal Tax Rate & $38 \%$ & $30 \%$ \\
\hline
\end{tabular}

\section{Results and Discussions}

\subsection{Celentano Hall PV System Performance}

Actual electricity generation data from the installed Celentano Hall PV system was monitored during the project. Consecutive ten-month performance data was collected and analyzed as part of this research. Table 6 presents monthly electricity generation from the start of the array's operation together with monthly average temperatures. The peak electricity generation occurred during summer while low electricity was generated during winter.

\subsection{Estimation of Annual Energy Production}

In addition to collecting actual data as part of the study, estimation of electricity generation was deemed necessary to forecast future performance of the array, which was then used as an input into the economic model. 
1 Table 6. Celentano Hall PV system electricity generation (actual) and monthly average

2 temperatures at the location $[49,50]$

\begin{tabular}{lcc}
\hline Month & $\begin{array}{c}\text { Monthly Electricity } \\
\text { Generated (kWh) }\end{array}$ & $\begin{array}{c}\text { Monthly Average } \\
\text { Temperature }\left({ }^{\circ} \mathbf{C}\right)\end{array}$ \\
\hline January & 4,513 & 0.0 \\
\hline February & 2,911 & -0.6 \\
\hline March & 6,552 & 3.9 \\
\hline April & 7,686 & 9.4 \\
\hline May & 10,735 & 13.9 \\
\hline June & 9,326 & 18.9 \\
\hline July & 10,617 & 22.2 \\
\hline August & 10,547 & 23.3 \\
\hline September & 8,609 & 18.9 \\
\hline October & 6,856 & 13.3 \\
\hline November & 4,115 & 8.3 \\
\hline December & 2,777 & 2.8 \\
\hline \multicolumn{1}{c}{ Total } & $\mathbf{8 5 , 2 4 4}$ & \\
\hline
\end{tabular}

The annual sun path is one of the most effective environmental factors included in solar PV performance measurement. The tilt angle of modules has a great impact on the amount of solar radiation incident collected on the surface. Theoretically, the maximum annual module power occurs when the modules are facing the sun path as shown in Figure 7(a). Figure 7 (b) shows the maximum amount of solar insolation with respect to the sun path of the studied region and the module angle. The most ideal orientation and angle for the Celentano Hall is facing directly south, at an angle of approximately 12 degrees, and this orientation would optimize the PV generation at this location. 


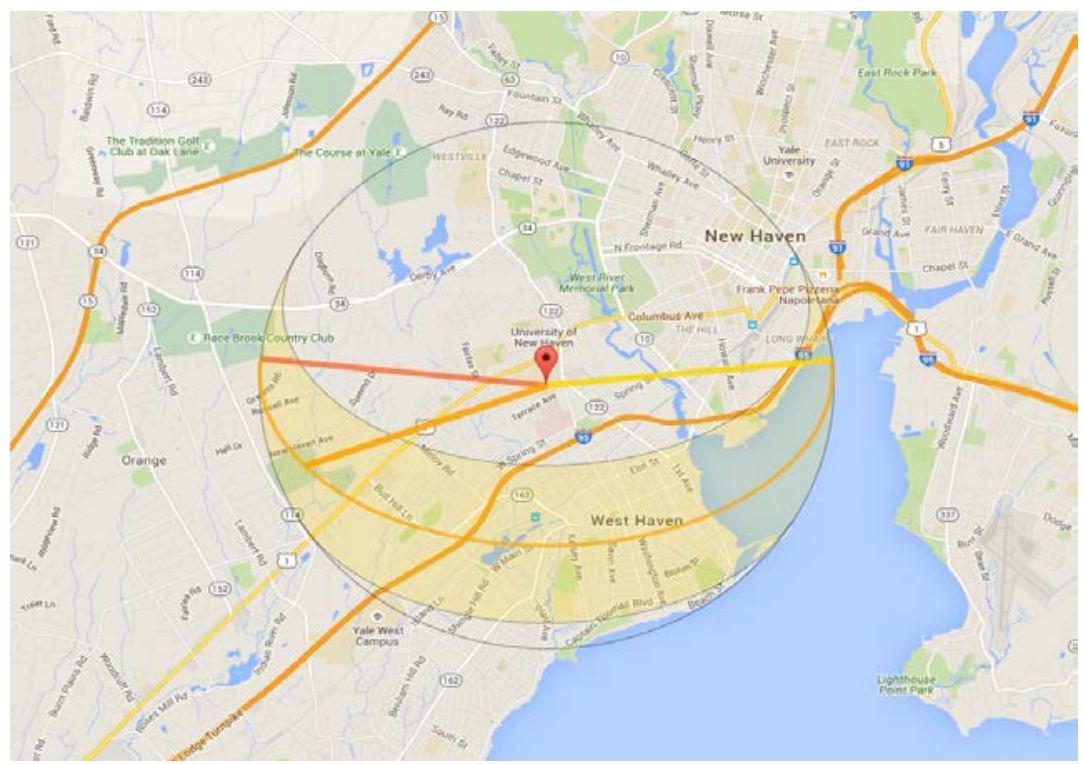

(a) Sun path on the studied region (West Haven, Connecticut)

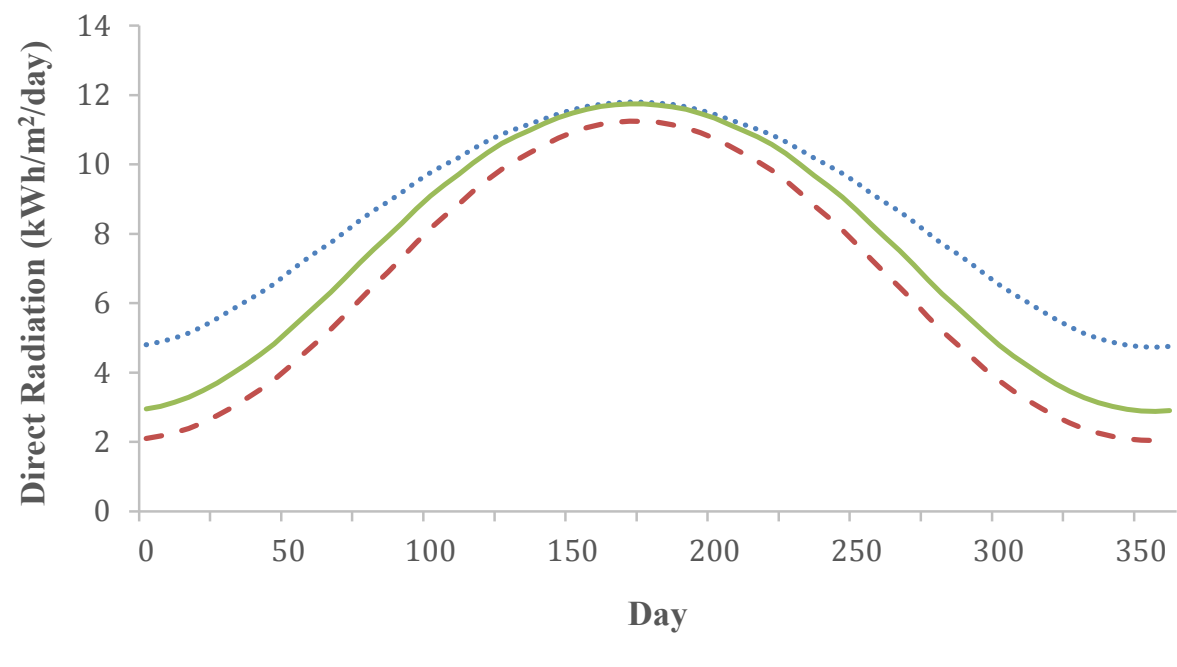


Table 7. Celentano Hall PV system energy generation calculation

\begin{tabular}{lrl}
\hline \multicolumn{1}{c}{ Celentano Hall PV Array } & Latitude $41.29^{\circ}$ & Longitude $72.96^{\circ}$ \\
\hline \hline Elevation Angle of Sun $(\alpha)$ & 48.71 & degree \\
Angle of Module & 12.00 & degree \\
Declination Angle $(\delta)$ & 0.00 & degree \\
Array Tilt $(\beta)$ & 12.00 & degree \\
Latitude $(\Phi)$ & 41.29 & degree \\
No. of Panels & 228 & \\
Panel Size & 1.93 & $\mathrm{~m}^{2}$ \\
S horizontal $^{2}$ & $1,393.23$ & $\mathrm{kWh} / \mathrm{m}^{2} . \mathrm{y}$ \\
S $_{\text {incident }}$ & $1,854.22$ & $\mathrm{kWh} / \mathrm{m}^{2} . \mathrm{y}$ \\
S module & $1,617.17$ & $\mathrm{kWh} / \mathrm{m}^{2} . \mathrm{y}$ \\
Annual Solar Energy Output & & \\
E=A*r*H*PR & & \\
A (Total Solar Panel Area) & 440.62 & $\mathrm{~m}{ }^{2}$ \\
r (Solar Panel Yield) & 0.155 & \\
h (Annual Avg. Solar Radiation) & $1,617.17$ & $\mathrm{kWh} / \mathrm{m}^{2} . \mathrm{y}$ \\
pr (Performance Ratio) & 0.75 & \\
E (Annual Solar Energy Output) & $82,834.10$ & $\mathrm{kWh}$ \\
\hline
\end{tabular}

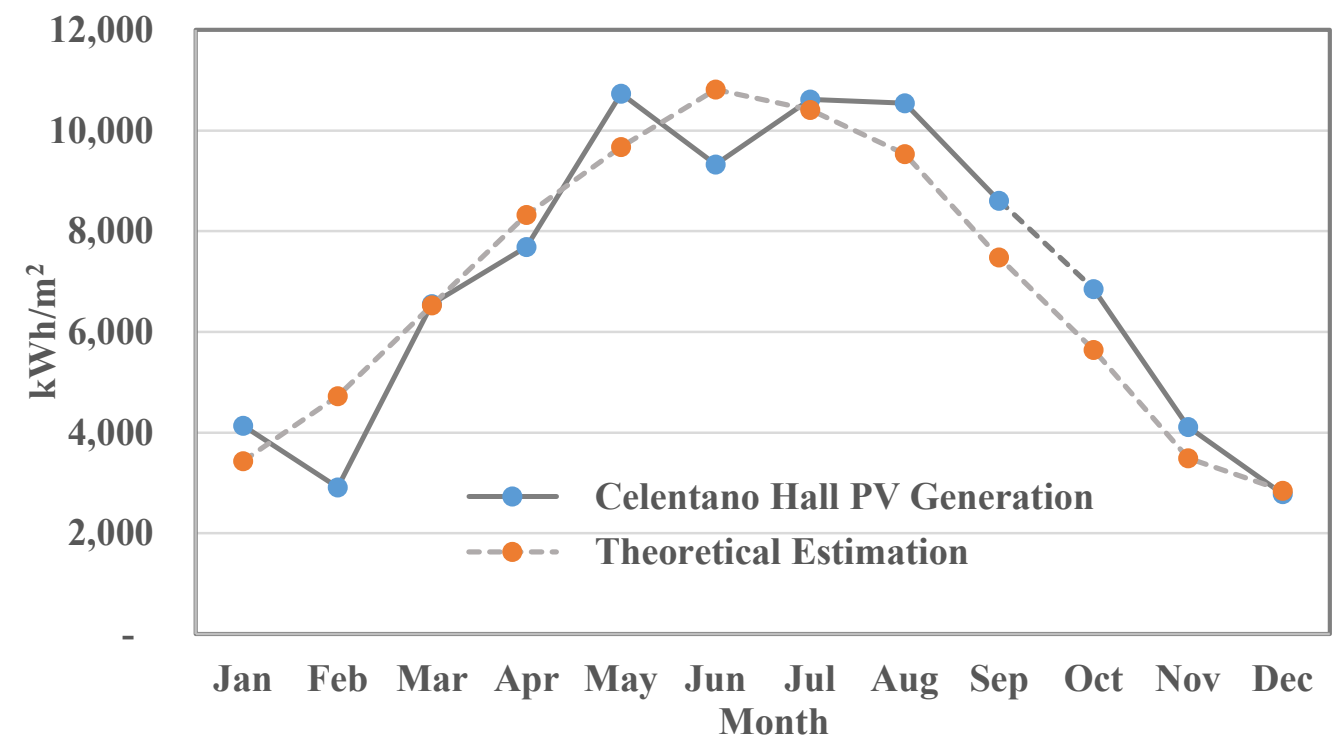

Figure 8. Comparison of actual Celentano Hall PV output and estimated electricity generation

The actual (measured) data in Figure 8 were collected from January 16, 2015 to April 15, 2016. In the figure, the data for January, February, March, and April were averaged. As actual data are dependent on weather conditions, irregular weather conditions may cause other discrepancies in the trends. For example, more snow or precipitation and cloud cover in February and June were responsible for the mismatch between actual and estimated trends. According to weather history in New Haven, Connecticut, there were more rain or snow days in February and 
June, 2015 than the normal years. The values on the weather variables could be analyzed by using the simulation software developed by the FAE group from UFPE (Alternative Energy Source - Universidad Federal de Pernambuco) [51]. Over the long term however, total electricity generation of the PV system was expected to be close to the estimated value.

\subsection{Economic Analysis}

The turn key installation cost of the PV array was $\$ 288,500$ for a PV system with $67 \mathrm{~kW}$ capacity. Annual electricity generation of the system was estimated to be $82,800 \mathrm{kWh} / \mathrm{yr}$. Based on the financial factors and values assigned during the economic analysis, the installed cost of the solar PV system analyzed can be calculated as $\$ 4.29 / \mathrm{W}$.

It is interesting to note that the calculated value of $\$ 4.29 / \mathrm{W}$ is $27 \%$ lower than the unit cost value of $\$ 5.91 / \mathrm{W}$ presented as the CT state average by the Open PV Project database, administered by NREL [52]. Still, the 127.2 MW installed solar PV capacity reported by the database is reasonably close to the $129 \mathrm{MW}$ proposed by the EIA [13], hence lending credence to the database. While the difference in unit cost may be due to a number of reasons such as differences in project size, use of panels that have different technology, or different company practices, it is important to realize the variation in unit price of installed cost, as the value would have an important impact on the feasibility and payback period calculations of a project.

ZRECs constitute an important determinant in assessing the feasibility of PV systems as it provides long term support to bring down the unit cost of electricity generated through the PV system. The installed array was awarded $\$ 0.148 / \mathrm{kWh}$ ZRECs for electricity generated by the PV system. Based on annual electricity generation, the University would receive around $\$ 12,000$ during its first year, with a subsequent $0.5 \%$ annual decrease due to the module degradation. Still, UNH would benefit from $\$ 180,000$ in financial support provided by the program over the duration of the incentive.

The return on investment (ROI) represents the cost effectiveness of a PV system project. The profitability and economic aspects of the Celentano Hall PV system were determined by evaluating the economic indicators: Net Present Value (NPV), Internal Rate of Return (IRR), Simple Payback Period (SPBP), Discounted Payback Period (DPBP), Discounted Cash Flow (DCF), and Profitability Index (PI). The life expectancy of the solar panels were assumed to be 25 years as determined by the most of solar companies. The current 30 year fixed loan rate is $3.72 \%$, and therefore, the discount rate of 5\% was used for this analysis [53-56].

Net present value is a simple calculation of difference between the present value of cash inflows and outflows. NPV compares the value of an investment today to the future value of the money based on inflation and returns. It is one of the most effective value to assess the profitability of a long term project. A positive value of NPV indicates a favorable investment.

$$
\mathrm{NPV}=\sum_{t=1}^{T} \frac{C_{t}}{(1+r)^{t}}-C_{o}
$$

Internal rate of return (IRR) is an economic indicator that analyzes the profitability of a project by comparing to the discount rate. A project is more desirable as the difference between IRR and discount rate becomes larger.

$$
0=\sum_{y=1}^{y} \frac{C_{y}}{(1+I R R)^{y}}-C_{0}
$$

The simple payback period evaluates the risk associated with a long-term project. SPBP is the time required for an initial investment to generate a positive cash flow.

$$
\mathrm{SPBP}=\frac{\text { Initial Investment }}{\text { Annual Savings } / y}
$$


Discounted Cash Flow (DCF) is an anticipated revenue stream generated from an investment at a given period. Profitability index (PI) a simple value between 1 and 2 indicating the ratio of payoff to the initial investment. If the PI value of a project is 2 , the investment is expected to be doubled within the project life time. Thus, a project with PI value greater than 1 is acceptable. DCF and PI can be calculated using the formulas,

$$
\begin{aligned}
& \mathrm{DCF}=\frac{C F}{(1+r)^{y}} \\
& \mathrm{PI}=\frac{N P V}{\text { Initial Investment }}+1
\end{aligned}
$$

Table 8 summarizes Cenlentano Hall PV system economic parameters. As shown in the table, the result of the economic analysis on the campus-wide PV system at UNH suggests that the project is profitable since PI is larger than 1.0. The NPV for Celentano Hall PV system is $\$ 81,996$, and IRR of $8.74 \%$ is well over the discounted rate of $6 \%$, both indicating that the project is profitable. The project is expected to generate a positive cash flow after simple payback period of 11 years.

Table 8. Estimated Cenlentano Hall PV system economic parameters

\begin{tabular}{llr}
\hline Net Present Value & $(\mathrm{NPV})$ & $\$ 81,996$ \\
\hline Internal Rate of Return & $(\mathrm{IRR})$ & $8.74 \%$ \\
\hline Simple Payback Period & (SPBP) & 11 years \\
\hline Simple Cash Flow & (SCFy) & $\$ 360,290$ \\
\hline Discounted Cash Flow & (DCFy) & $\$ 106,395$ \\
\hline Profitable Index & (PI) & 1.28 \\
\hline
\end{tabular}

\subsection{Payback Period and Lifetime Savings}

The estimated annual solar energy generated by the Celentano Hall PV system during its first year was calculated to be $82,800 \mathrm{kWh}$. However, electricity generated is expected to decline over the lifetime of the PV system by the factor of module degradation. Based on the analysis presented in Table 9, the installed PV system was expected to generate a positive cash flow in 11 years, hence the payback period. Furthermore, the system was estimated to accrue around $\$ 360,000$ by its end of life after 25 years.

\subsection{Extension of Economic Analysis to Other Buildings at UNH}

Economic analysis for a campus-wide PV system installation was conducted to assess system feasibility for other buildings at the UNH campus. The analysis was based on data obtained for the Celentano Hall PV system, and was extrapolated to other buildings by taking into account their actual characteristics and limitations such as dimensions, roof types, their ability to structurally accommodate additional loads, and historical electricity consumption of each building. After an initial analysis of roof type, size, and orientation, 26 out of 35 buildings were selected for further analysis. The selected 26 buildings, shown in Figure 9, were unobstructed by nearby trees or were not shaded by other nearby buildings, and their roofs were suitable to install PV arrays large enough to qualify for government incentives. The estimated 
1 annual energy production and payback periods were calculated based on the same method

2 described in section 4.4 .

Table 9. Payback period and estimated annual cash flow calculations for the Celentano Hall PV system up to its 25 year lifetime. Values within parenthesis indicate negative values.

\begin{tabular}{ccccccccc}
\hline Year & $\begin{array}{c}\text { Installation } \\
\text { Cost and } \\
\text { O\&M }(\$)\end{array}$ & $\begin{array}{c}\text { Electricity } \\
\text { cost } \\
(\$ / \mathrm{kWh})\end{array}$ & $\begin{array}{c}\text { Electricity } \\
\text { Generation } \\
(\mathrm{kWh})\end{array}$ & $\begin{array}{c}\text { Electricity } \\
\text { Cost } \\
\text { Savings } \\
(\$)\end{array}$ & $\begin{array}{c}\text { ZREC } \\
\text { Credit } \\
(\$)\end{array}$ & $\begin{array}{c}\text { Insurance } \\
(\$)\end{array}$ & $\begin{array}{c}\text { Effective } \\
\text { Cash } \\
\text { Flow }(\$)\end{array}$ & $\begin{array}{c}\text { Cumulative } \\
\text { Cash Flow } \\
(\$)\end{array}$ \\
\hline \hline 1 & $(288,500)$ & 0.170 & 82,834 & 14,082 & 12,259 & $(490)$ & $(262,649)$ & $(262,649)$ \\
2 & $(673)$ & 0.176 & 82,420 & 14,502 & 12,198 & $(505)$ & 25,522 & $(237,127)$ \\
10 & $(852)$ & 0.232 & 79,180 & 18,345 & 11,719 & $(640)$ & 28,572 & $(19,781)$ \\
11 & $(878)$ & 0.240 & 78,784 & 18,893 & 11,660 & $(659)$ & 29,016 & 9,235 \\
19 & $(1,112)$ & 0.316 & 75,687 & 23,900 & - & $(835)$ & 21,953 & 214,123 \\
20 & $(1,145)$ & 0.327 & 75,309 & 24,613 & - & $(860)$ & 22,608 & 236,730 \\
25 & $(1,327)$ & 0.388 & 73,445 & 28,509 & - & $(997)$ & 26,184 & 360,289 \\
\hline
\end{tabular}

6

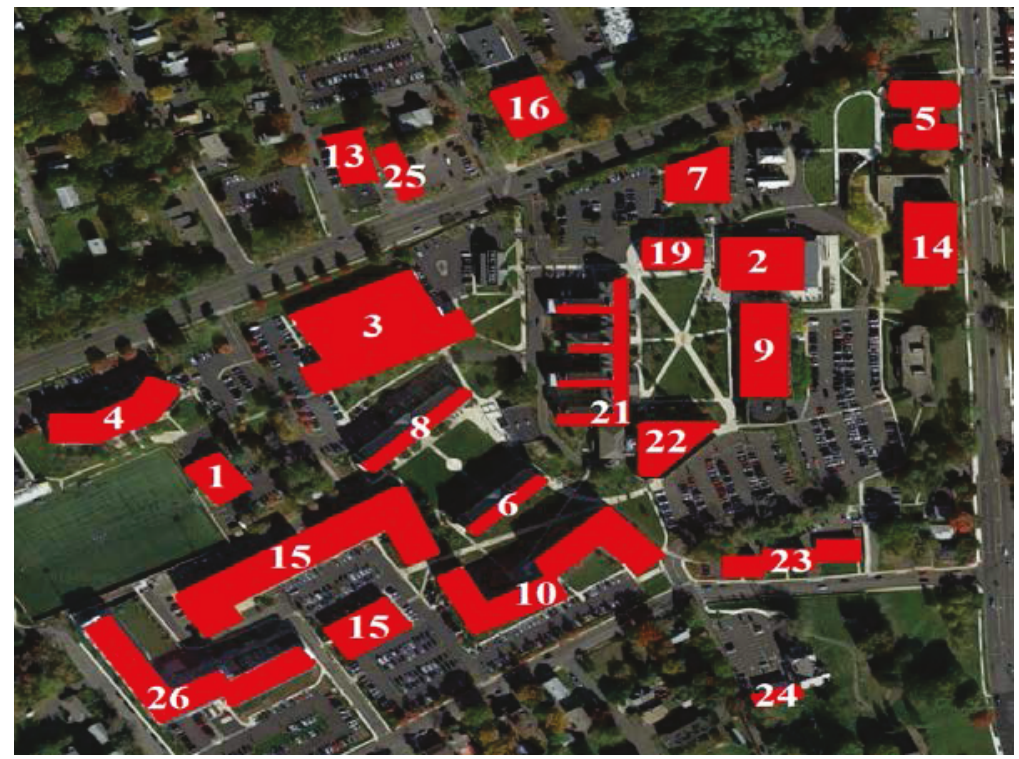

\section{I.}

8 Figure 9. Section of the UNH Main campus aerial view

9 Note. Shaded areas correspond to building rooftops, where numbers indicate individual buildings. 22 of the 26 selected buildings for further analysis were shown in the figure.

Each roof was tested for its structural capacity to hold additional weight imposed by solar panels weighing about $27 \mathrm{~kg}$ each. If a roof has to be replaced before the design lifetime of the PV systems, taken as 25 years in this study, the roof was considered to be unsuitable for new PV installation as the costs associated with uninstalling PV arrays would be inhibiting [58].

A primary concern was the number of potential PV panels that could be practically fitted onto the roofs of various buildings, as earlier analysis on Celentano Hall had indicated that the 
are of Celentano Hall was $2,186 \mathrm{~m}^{2}$, only 228 modules corresponding to $440 \mathrm{~m}^{2}$ were installed. In other words, each PV module may be assumed to practically require $9.6 \mathrm{~m}^{2}$ for installation.

Table 10 present results of the economic analysis extrapolated to the UNH campus through the 26 buildings selected. Assuming similar spatial limitations in the placement of PV modules, a campus-wide PV installation would require somewhat more than 3,500 PV modules. Based on cash flow analysis at system end of life, all PV arrays returned a profit. The payback period ranged between 8-12 years depending on the building and its characteristics.

The average annual electricity savings from a campus-wide PV installation on the roofs of the 26 buildings was estimated to be a $\$ 250,000$. Therefore, total savings of approximately $\$ 6.3$ million could be expected over the 25 year design lifetime of the system. These numbers should be evaluated with regards to current expenditures of the University. Energy costs make up a significant portion of the overall university operation expenses, where UNH was spending approximately $\$ 3$ million annually for electricity.

Table 10. Building characteristics and electricity consumption, estimated electricity generation, and payback period calculated for each building

\begin{tabular}{|c|c|c|c|c|c|c|c|}
\hline $\begin{array}{l}\text { Bldg. } \\
\text { No. }\end{array}$ & Building & $\begin{array}{c}\text { Annual Elec. } \\
\text { Consumption } \\
(\mathrm{kWh})\end{array}$ & $\begin{array}{l}\text { Roof } \\
\text { Area } \\
\left(\mathrm{m}^{2}\right)\end{array}$ & $\begin{array}{c}\text { Estimated } \\
\text { No. of } \\
\text { Solar } \\
\text { Modules }\end{array}$ & $\begin{array}{c}\text { Estimated } \\
\text { Annual } \\
\text { Generation } \\
(\mathrm{kWh})\end{array}$ & $\begin{array}{l}\text { Cash Flow } \\
\text { after } 25 \\
\text { Years }(\$)\end{array}$ & $\begin{array}{c}\text { Payback } \\
\text { Period } \\
\text { (Yr) }\end{array}$ \\
\hline 1 & Arbeiter Maenner Chor & 37,789 & 248 & 26 & 9,446 & 63,650 & 9 \\
\hline 2 & Bartels Hall & 985,520 & 1,493 & 156 & 56,675 & 223,711 & 12 \\
\hline 3 & Beckerman Rec. Center & 719,120 & 3,755 & 392 & 142,417 & 724,393 & 11 \\
\hline 4 & Bergami Hall & 597,600 & 1,196 & 125 & 45,413 & 198,914 & 11 \\
\hline 5 & Bethel Hall & 980,580 & 929 & 97 & 35,241 & 128,169 & 12 \\
\hline 6 & Bixler Hall & 285,480 & 1,048 & 109 & 39,601 & 171,862 & 11 \\
\hline 7 & Bookstore/Security & 157,160 & 702 & 73 & 26,521 & 141,020 & 10 \\
\hline 8 & Botwinik Hall & 331,840 & 744 & 78 & 54,133 & 235,248 & 11 \\
\hline 9 & Buckman Hall & 600,236 & 1,570 & 164 & 59,582 & 270,522 & 11 \\
\hline 10 & Celentano Hall & $1,425,900$ & 2,186 & 228 & 82,834 & 360,290 & 11 \\
\hline 11 & Charger Gymnasium & 531,120 & 1,651 & 172 & 62,489 & 274,897 & 11 \\
\hline 12 & Charger Plaza & 270,105 & 795 & 83 & 30,155 & 201,826 & 9 \\
\hline 13 & Dental Center & 61,280 & 805 & 84 & 30,518 & 206,605 & 9 \\
\hline 14 & Dodds Hall & 948,960 & 2,133 & 223 & 81,018 & 351,481 & 11 \\
\hline 15 & $\begin{array}{c}\text { Dunham, Sheffield, } \\
\text { Winchester Halls }\end{array}$ & 827,200 & 3,601 & 376 & 136,604 & 542,258 & 12 \\
\hline 16 & Echlin Hall & 524,160 & 897 & 94 & 34,151 & 138,231 & 12 \\
\hline 17 & Forest Hills Apartments & 207,648 & 2,916 & 304 & 110,445 & 674,862 & 10 \\
\hline 18 & Gate House & 37,320 & 194 & 30 & 10,899 & 66,280 & 10 \\
\hline 19 & Henry C. Lee Institute & 301,920 & 389 & 41 & 14,896 & 59,880 & 12 \\
\hline 20 & Kaplan Hall & 229,506 & 668 & 70 & 25,432 & 123,095 & 11 \\
\hline 21 & Maxcy Hall & 700,320 & 900 & 94 & 34,151 & 143,469 & 11 \\
\hline 22 & Peterson Library & 117,200 & 1,380 & 144 & 52,316 & 279,161 & 10 \\
\hline 23 & Ruden Street Apartments & 66,583 & 606 & 63 & 22,888 & 154,564 & 9 \\
\hline 24 & South Campus Hall & 108,760 & 279 & 29 & 10,536 & 64,765 & 10 \\
\hline 25 & Subway Building & 15,980 & 275 & 29 & 10,536 & 92,390 & 8 \\
\hline \multirow[t]{2}{*}{26} & West Side Hall & 117,200 & 2,340 & 244 & 88,647 & 408,136 & 11 \\
\hline & Total & $11,186,487$ & 33,700 & 3,526 & $1,307,543$ & $6,299,679$ & 11 \\
\hline
\end{tabular}


Economic benefits of a campus-wide solar PV implementation would have regional impacts as well. Through the use of the JEDI Model, the number of jobs that may be created as a result of the investment was calculated. By inputting project characteristics of the installed Celentano Hall PV system into the model, results indicate that 2 jobs were created locally. While this number is not much, it must be kept in perspective that the installed array was only a $67 \mathrm{~kW}$ system. Should the University install PV arrays on the other analyzed buildings, the model yields 31 jobs created during construction and installation and 0.4 jobs during operation years.

\subsection{Assumptions and Further Discussion}

In order to analyze the economic feasibility of Celentano Hall PV system, it is essential to consider the assumptions made on the economic parameters. First, the time period for the financial analysis was considered to be 25 years, which was same as the life expectancies of typical solar panels. The discount rate and inflation rate were also assumed to be constant for 25 years. For the feasibility assessment on the PV system for the entire campus, only ZREC incentive was considered in the calculation because the Celentano Hall only qualified for ZREC. There are more government incentive programs in Connecticut, and a greater profitability can be expected if the project qualifies for other incentives. However, this study was conducted based on the data collected from Celentano Hall, thus the assumption was validated. In order to calculate the expected savings from electricity usage, future electricity rates were assumed to increase by inflation rate of $3 \%$ per year, which was determined based on the past electricity rate trend. The operation and maintenance cost for Celentano Hall was estimated to be $\$ 10$ per $\mathrm{kWh}$ generation. Since the modules for the campus-wide PV system will be managed by the same company, it is acceptable to apply the same rate of O\&M to the campus-wide PV economic analysis. Currently only six states mandate 'Feed in Tariff' in U.S. and Connecticut is not one of them.

Different methods can be used to achieve the objective of the study, to analyze the feasibility of campus-wide PV system. Solar irradiation at the studied region is required to calculate the theoretical estimation of solar PV generation. While different approaches are available, two most effective methods are clearness index and tilt angle of the module. Since the optimum tilt angle for the studied region was given from the installed PV system, tilt angle method was used to obtain the solar irradiation instead of clearness index, which required complex calculations.

The advantages of using NPV as an economic parameter when analyzing a long-term project are its realistic reinvestment assumptions and the ability to modify discount rate, allowing analysis on different risk levels. However, NPV requires assumed value for cost of capital. Depending on the level of assumed cost of capital, the investment can be predicted to be either too low or too high. The advantages of IRR method are it considers the time value of money when evaluating a profitability of a project, and it is simple to interpret. However, the reinvestment assumed for this calculation is unrealistic, because IRR method ignores the actual dollar value of benefits. Discounted payback period shows a reliable result than a simple payback period because it considers the time value of money. However, this method ignores the cash flows after the payback period. Despite the advantages associated with these economic indicators, this study considered the all into analysis, because the results for all indicators validated the profitability of the project. 


\section{Conclusions}

The primary objective of this study was to assess the economic feasibility of expanding solar PV systems at the UNH campus under realistic constraints, by analyzing data from a recently implemented solar array on campus. In order to accomplish this objective, an economic analysis model was created based on data collected from Celentano Hall. The annual estimated amount of solar generation was $82,800 \mathrm{kWh}$, while the total cash flow was calculated as $\$ 360,000$ over the design lifetime of the PV system. The payback period calculated by a multi factorial analysis was determined to be 11 years.

In addition, the result of the economic analysis on the campus-wide PV system at UNH suggests that the project is profitable since PI is larger than 1.0. The NPV for Celentano Hall PV system is $\$ 81,996$, and IRR of $8.74 \%$ is well over the discounted rate of $6 \%$, both indicating that the project is profitable.

Application of the economic model to other buildings on campus with varying characteristics, roof sizes, and electricity consumption yielded similar results, where all 26 buildings analyzed generated a positive cash flow over the lifetime of the system. The payback period calculated for other buildings ranged between 8-12 years.

In addition to geography and other environmental factors, state or federal incentives play an important role in current markets for PV systems [59]. For PV installations in CT, such incentives closely affect the payback period of a project and therefore may determine the outcome of the project. Most of the 26 buildings analyzed would qualify for ZREC incentives. The average annual electricity savings from a campus-wide PV installation on building roofs was estimated to be a $\$ 250,000$. Total savings of approximately $\$ 6.3$ million could be expected over the 25 year design lifetime of the system. These numbers should be evaluated with regards to current expenditures the University has. Energy costs make up a significant portion of the overall university operation expenses, where UNH was spending approximately \$3 million annually for electricity.

The conclusion of this research proved the feasibility of PV system installation at UNH with a reasonable payback period given ZREC incentives can be secured for a project. The results of the study together with its economic analysis could be used to assess the feasibility of PV systems at other universities in CT or in neighboring states that share similar climatic characteristics and economic factors.

Installing PV systems on campus not only generates renewable energy that is used onsite, thereby reducing building operation expenditures, but also can be used as an effective tool to raise the level of awareness of the greater university community towards renewable energy and towards sustainable efforts in general. Most students in higher education will graduate in a few years and start making decisions on where they live and work. Being exposed to renewable energy inherently during their higher education may alter their perceptions and expectations, therefore generating long term impacts.

\section{Acknowledgement}

The authors acknowledge the University of New Haven Research Fellowship Program, Mr. and Mrs. Carrubba, and other sponsors of the program. The authors are grateful for the technical support and contribution from the Vice President of UNH Facilities, Mr. Annino, and the Director of Sustainability Services at Celtic Energy, Inc., Chris Lotspeich. 


\section{References}

1. EIA, 2015a. Table 7.1 Electricity Overview (Billion Kilowatthours), U.S. Energy Information Administration / Monthly Energy Review, U.S. Department of Energy, Washington, D.C.

2. UNFCCC, 2015. Conference of the Parties, United Nations Framework Convention on Climate change, FCCC/CP/2015/L.9/Rev.1.

3. Whitehouse, 2015a. U.S. Leadership and the Historic Paris Agreement to Combat Climate Change, Office of the Press Secretary, The White House, Accessed April 2016, https://www.whitehouse.gov/the-press-office/2015/12/12/us-leadership-and-historicparis-agreement-combat-climate-change

4. Whitehouse, 2015b. FACT SHEET: U.S. Reports its 2025 Emissions Target to the UNFCCC, Office of the Press Secretary, The White House, Accessed April 2016, https://www.whitehouse.gov/the-press-office/2015/03/31/fact-sheet-us-reports-its-2025emissions-target-unfecc

5. EPA, 2015. Total U.S. Greenhouse Gas Emissions by Economic Sector in 2013, Electricity Sector Emissions, Sources of Greenhouse Gas Emissions, U.S. Environmental Protection Agency, Accessed April 2016, http://www3.epa.gov/climatechange/ghgemissions/sources/electricity.html

6. Aktas, A.Z., 2015. A Review and Comparison of Renewable Energy Strategies or Policies of Some Countries, $4^{\text {th }}$ International Conference on Renewable Energy Research and Applications, Palermo, Italy.

7. Chatzivasileiadis, S., Ernst, D., \& Andersson, G. 2013. The Global Grid. Renewable Energy, Vol. 57, pages 372-383.

8. Feldman, D., Barbose, G., Margolis, R., Bolinger, M., Chung, D., Fu, R., Seel, J., Davidson, C., Darghouth, N., Wiser, R., 2015. Photovoltaic System Pricing Trends Historical, Recent, and Near-Term Projections 2015 Edition, U.S. Department of Energy, NREL/PR-6A20-64898, August 2015.

9. DOE, 2014. U.S. Total Solar Electricity Installed Capacity and Generation, 2013 Renewable Energy Data Book, Office of Energy Efficiency and Renewable Energy, U.S. Department of Energy, pp. 64.

10. Bazilian, M., Onyeji, I., Liebreich, M., Macgill, I., Chase, J., Shah, J., Zhengrong, S. 2013. Re-considering the economics of photovoltaic power. Renewable Energy, Vol. 53, pages 329-338.

11. EIA, 2015b. Table 6.2.B. Net Summer Capacity Using Primarily Renewable Energy Sources and by State, September 2015 and 2014 (Megawatts), Electric Power Monthly with Data for September 2015, U.S. Energy Information Administration, U.S. Department of Energy, Washington, D.C.

12. DOE, 2015. Photovoltaics, Office of Energy Efficiency and Renewable Energy, U.S. Department of Energy.

13. EIA, 2015c. Table 5.6.A. Average Price of Electricity to Ultimate Customers by End-Use Sector, Electric Power Monthly with Data for September 2015, U.S. Energy Information Administration, U.S. Department of Energy, Washington, D.C.

14. Ma, W.W., et. al. 2016. Climate change impacts on techno-economic performance of roof PV solar systems in Australia. Renewable Energy, Vol. 88, Page 430-438. 
15. Baurzhan, S. and Jenkins, G. 2016. Off-grid solar PV: Is it an affordable or appropriate solution for rural electrification in Sub-Saharan African countries? Renewable and Sustainable Energy Reviews, Vol. 60, Issue C, Pages 1405-1418.

16. Shrimali, G., et.al. 2016. Cost-effective policies for reaching India's 2022 renewable targets. Renewable Energy. Volume 93, pages 255-268.

17. Liu, X., Hoekman, S. K., Robbins, C., and Ross, P. 2015. Lifecycle climate impacts and economic performance of commercial-scale solar PV systems: A study of PV systems at Nevada's Desert Research Institute (DRI). Solar Energy. Volume 119, Pages 561-572.

18. Kurdgelashvili, L., Li, J., Shih, C. H., and Attia, B. 2016. Estimating technical potential for rooftop photovoltaics in California, Arizona and New Jersey. Renewable Energy. Vol. 95, pages 286-302.

19. Dautremont-Smith, J., Cortese, A.D., Dyer, G., Walton, J., 2009. ACUPCC Implementation Guide - Information and Resources for Participating Institutions Version 1.1, American College and University Presidents Climate Commitment.

20. Second Nature, 2014. 2014 Annual Report, Second Nature, Accessed April 2016, http://annualreport.secondnature.org/2014/

21. Xie, Y., Chang, B, Starcher, K., Carr, D., Chen, G. and Leitch, K. 2013. Installation of $42 \mathrm{~kW}$ Solar Photovoltaics and 50kW Wind Turbine Systems. Journal of Green Building, Vol. 8, Issue 3.

22. NREL, 2015a. Solar Maps - Photovoltaics, National Renewable Energy Laboratory, U.S. Department of Energy, Accessed April 2016, http://www.nrel.gov/gis/solar.html

23. Fitzpatrick, J. 2014. University of New Haven - Soundview Hall, Photovoltaic System, Bella Energy, Printed Brochure.

24. Rani, B., Srikanth, M., Ilango, G., \& Nagamani, C. 2013. An active islanding detection technique for current controlled inverter. Renewable Energy, Vol. 51, pages 189-196.

25. Eldin, S., Abd-Elhady, M., \& Kandil, H. 2016. Feasibility of solar tracking systems for PV panels in hot and cold regions. Renewable Energy, Vol. 85, pages 228-233.

26. Branker, K., Pathak, M.J.M., Pearce, J.M., 2011. A Review of Solar Photovoltaic Levelized Cost of Electricity, Renewable and Sustianable Energy Reviews, 15(9), 44704485.

27. Hanwha, 2013. Hanwha Solar Specification, HSL 721. Poly UL. Hanwha SolarOne. Printed Brochure.

28. AASHE, 2015. Solar Photovoltaic Installations in Connecticut, The Association for the Advancement of Sustainability in Higher Education, Accessed April 2016, http://www.aashe.org/resources/campus-solar-photovoltaic-installations/state/CT/.

29. ConnColl, 2010. Environmental Connections, Fall 2010 Newsletter, Goodwin-Niering Center for the Environment at Connecticut College, Accessed April 2016, https://www.conncoll.edu/media/website-media/centers/goodwinniering/greenlivingdocs/fall2010_GNCE_nwsltr.pdf.

30. ConnColl, 2015. Connecticut College Sustainability Update May 2015, Accessed April 2016, https:/www.conncoll.edu/media/website-media/sustainabilitydocs/Conn-CollegeSustainability-Update-May-2015-.pdf.

31. Wesleyan, 2012. Wesleyan University, News @ Wesleyan, Freeman Athletic Center Celebrates New Solar Panels at Dedication Ceremony, Accessed April 2016, http://newsletter.blogs.wesleyan.edu/2012/02/13/freemansolardedication/http://newsletter .blogs.wesleyan.edu/2012/02/13/freemansolardedication/. 
32. Yale, 2015. Solar Energy Use at Yale, Yale Sustainability, Accessed April 2016, http://sustainability.yale.edu/planning-progress/areas-focus/energy/renewable-energyalternative-fuel-yale/solar-energy-user-yale.

33. AVERT, 2014. Avoided Emissions and Generation Tool User Manual version 1.2, U.S. Environmental Protection Agency, Office of Air and Radiation, Climate Protection Partnerships Division.

34. Fisher, J., DeYoung, R.K., Santen, N.R., 2015. Assessing the Emission Benefits of Renewable Energy and Energy Efficiency Using EPA's Avoided Emissions and Generation Tool (AVERT), 2015 International Emission Inventory Conference "Air Quality Challenges: Tackling the Changing Face of Emissions", San Diego, CA.

35. YaleNews, 2015. West Campus solar array to generate 1.6 million kilowatt hours of electricity yearly, Accessed April 2016, http://news.yale.edu/2015/10/08/west-campussolar-array-generate-16-million-kilowatt-hours-electricity-yearly

36. CCAT, 2012. Preliminary Feasibility Study and Strategic Deployment Plan for Renewable and Sustainable Energy Projects, University of Connecticut.

37. NREL, 2015b. About JEDI Models, National Renewable Energy Laboratory, U.S. Department of Energy, Accessed April 2016, http://www.nrel.gov/analysis/jedi/about jedi.html.

38. Loomis, D., Jo, J., Aldeman, M.R., 2016. Economic impact potential of solar photovoltaics in Illinois, Renewable Energy, Vol. 87, pp. 253-258.

39. Croucher, M., 2012. Which state is Yoda?, Energy Policy, 42, pp.613-615.

40. Bezdek, R.H., 2007. Economic and Jobs Impacts of the Renewable Energy and Energy Efficiency Industries: U.S. and Ohio, Presented at SOLAR 2007, Cleveland, Ohio, Accessed April 2016, http://www.greenenergyohio.org/page.cfm?pageID=1386.

41. Solar Foundation, 2013. An Assessment of the Economic, Revenue, and Societal Impacts of Colorado's Solar Industry, Accessed April 2016, http://solarcommunities.org/wpcontent/uploads/2013/10/TSF_COSEIA-Econ-Impact-Report_FINAL-VERSION.pdf.

42. Macpherson, D., 2009. The Positive Economic Impact of Solar Energy on the Sunshine State, Briefings, Accessed April 2016, http://www.floridataxwatch.org/resources/pdf/04162009solarenergy.pdf.

43. Cetin, M., Egrican, N., 2011. Employment impacts of solar energy in Turkey, Energy Policy, 39(11), pp.7184-7190.

44. CT DEEP, 2015. Low-Emission Renewable Energy Credits (LREC) and Zero-Emission Renewable Energy Credits (ZREC), Department of Energy and Environmental Protection, State of Connecticut, Accessed April 2016, http://www.ct.gov/deep/cwp/view.asp?a=2715\&q=553942\&deepNav_GID=1626.

45. Marion, W., Wilcox, S. Solar Radiation Data Manual for Buildings, National Renewable Energy Laboratory, U.S. Department of Energy, Golden, Colorado.

46. EIA (Independent Statistics \& Analysis), 2015d. Table 5.3. Average Retail Price of Electricity to Ultimate Customers: Total by End-Use Sector, 2004 - August 2014 (Cents per Kilowatthour), Electric Power Monthly with Data for August 2015, U.S. Energy Information Administration, U.S. Department of Energy, Washington, D.C.

47. ICF, 2015. Economic Drivers of PV Report for ISO-New England, submitted by ICF International. 
48. Agdas, D., Srinivasan, R.S., Frost, K., and Masters, F.J., 2015. Energy Use Assessment of Educational Buildings: Toward a Campus-wide Sustainable Energy Policy, Sustainable Cities and Society 17, pp.15-21.

49. UNH, 2014. UNH Building Electricity Usage, Department of Facilities, University of New Haven.

50. NOAA, 2015. Monthly Climatological Summary (2015), National Oceanic and Atmospheric Administration, U.S. Department of Commerce, Accessed April 2016, http://www.ncdc.noaa.gov/cdoweb/datasets/GHCNDMS/stations/GHCND:USW00014758/detail

51. Tiba, C., and Beltrão, R. 2012. Siting PV plant focusing on the effect of local climate variables on electric energy production - Case study for Araripina and Recife. Renewable Energy, Vol. 48, pages 309-317.

52. NREL, 2015c. The Open PV Project, National Renewable Energy Laboratory, U.S. Department of Energy, Accessed April 2016, https://openpv.nrel.gov/search?state $=\mathrm{CT} \& z i p c o d e=$

53. Bustos, F., Toledo, A., Contreras, J., and Fuentes, A. 2016. Sensitivity analysis of a photovoltaic solar plant in Chile. Renewable Energy. Vol. 87, page 145-153.

54. Herrero, I., Rodilla, P., and Batlle, C. 2015. Electricity market-clearing prices and investment incentives: The role of pricing rules. Energy Economics, Vol. 47, pages 4251.

55. DrEAM Team. 2015. Impact of regulatory rules on economic performance of PV power plants. Renewable Energy. Vol. 74, page 78-86.

56. Rodrigues. et.al. 2016. Economic feasibility analysis of small scale PV systems in different countries. Solar Energy. Vo. 131, page 81-95.

57. Rehman, S., Bader, M. A., \& Al-Moallem, S. A. (2007). Cost of solar energy generated using PV panels. Renewable and Sustainable Energy Reviews, 11(8), 1843-1857. doi:10.1016/j.rser.2006.03.005

58. Fernández-Infantes, A., Contreras, J., and Bernal-Agustín, J. 2006. Design of grid connected PV systems considering electrical, economical and environmental aspects: A practical case. Renewable Energy, Vol. 31. Issue 13, pages 2042-2062.

59. Zhai, P. (2013). Analyzing solar energy policies using a three-tier model: A case study of photovoltaics adoption in Arizona, United States. Renewable Energy, Vol. 57, pages 317322. 